\title{
ROLE OF FIXED INVESTMENTS IN ECONOMIC GROWTH OF COUNTRY: LITHUANIA IN EUROPEAN CONTEXT
}

\author{
Vytautas Tvaronavičius $^{1}$, ManuelaTvaronavičiene ${ }^{2}$ \\ Vilnius Gediminas Technical University, \\ Saulètekio al. 11, 10223 Vilnius, Lithuania \\ E-mail: 1finansu.katedra@vv.vgtu.lt,2 manuela@vv.vgtu.lt \\ Received 3 February 2007; accepted 5 December 2007
}

\begin{abstract}
The paper aims to detect character of relationship between fixed investments and economic growth in Lithuania and predict plausible tendencies of further change of considered variables. In order to achieve the indicated task, authors concentrate themselves on two major questions. Firstly, quantitative relationships between investments into major areas of economic activities and Lithuanian economic growth are being estimated. Secondly, comparative analysis of Lithuanian pattern of investment and randomly taken developed European country is being performed. Authors seek to trace how the latter invested during its process of development. Concrete period of observation is being chosen taking into account the current level of Lithuanian economic development. Authors seek to trace plausible consistent patterns of development in terms of relationship between fixed investments and economic growth as countries develop. Obtained results might allow identifying the role of fixed investments, and, if to go further, facilitating forecasts of possible trends of fixed investment and corresponding economic growth.
\end{abstract}

Keywords: fixed investments, economic growth, Lithuania, Austria.

\section{Introduction:}

\section{theoretical background of the problem}

Many empirical and theoretical studies have attempted to explain the differences of economic growth rates across countries. Capital formation usually is primary focus of interest in analyzing economic growth. Empirical studies relating economic growth to capital formation have suggested that fixed investment is a major influence on economic growth. Despite a lot of studies using observations from a large number of countries emphasized significant relationships between growth rates and fixed investment rates, some, the most recent ones, suggest that fixed investments change their impact on economic growth as country develops. It means that other factors gradually might obtain bigger significance.

Aim of this paper is to examine the causal relationships between economic growth and fixed investments taking into account the stage of development achieved by a considered country. Our assumption is that countries might develop according to some consistent patterns. It means that at the lower level of economic development there could be stronger relationship between investment and economic growth. Character of considered relationship might change as country reaches a higher level of development. If certain consistent patterns of relationship between investment level and its structure and economic growth rate were detected, then predictions and corresponding policy implications for less developed countries might be drawn.

To return to main theoretical findings, several ones expressing the most typical approaches could be presented. The classical macroeconomic theory says that economic growth depends on fixed investment, or on gross fixed capital formation. Relationship between fixed capital formation shares of GDP and growth rates since World War II has led many writers, such as De Long and Summers (De Long, Summers 1991; De Long 1992), to conclude that the rate of capital formation, or, more specifically, of capital formation in the form of equipment, determines the rate of a country's economic growth. This approach is supported by Summers (De Long, Summers 2001). Notwithstand- 
ing grounded opinions presented above, other authors, such as Blomstrom (Blomstrom, et al. 2001) assert that strong association between equipment investment and growth does not prove causality. It is supposed that effects may result from growth in capital formation, so that rapid growth might lead to high rates of capital formation.

Hence, diametrically opposite approaches towards what is cause and what is consequence of economic growth do not exhaust questions related to fixed investment and growth. Another hub of discussion tackles a different role played by components of fixed investment. While authors mentioned above emphasize the role of equipment, representatives of another view, e.g., H. Dellas and V. Koubi (2001), claim that non-equipment investment (construction) seems to be a more significant contributor to growth, perhaps because it has more favourable effects on industrial employment (it is more labour intensive than equipment investment).

The shift of the EU economies towards larger service sectors arises speculations about growing significance of investments in IT-producing sectors (both in manufacturing and services), which by opinion of some authors might be considered as major driving factors of contemporary economic growth in some EU countries (Carone et al. 2006).

Not going into theoretical discussion about what is cause and what is consequence (fixed investment or economic growth), we frame our research as follows. Firstly, we adopt a premise that fixed investments cause economic growth. Secondly, besides quantitative esti-

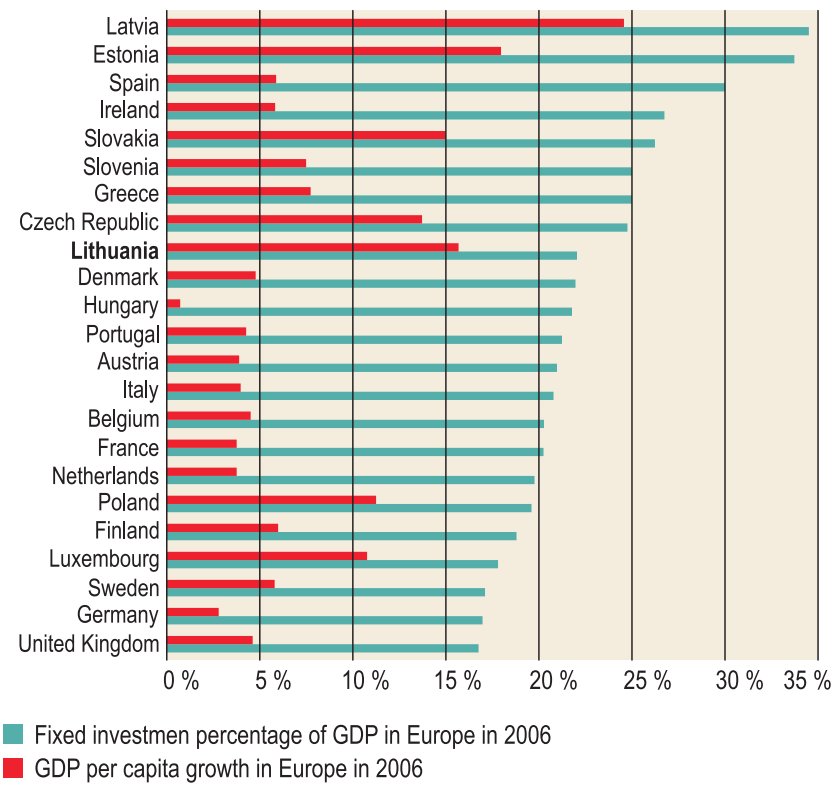

Fig. 1. Fixed investment percentage of GDP and GDP per capita growth in Europe in 2006; source: EUROSTAT (juxtaposed by authors) mation of the latter relationship, we seek to find out what role separately taken components of fixed investment, including equipment and construction, play in accelerating of economic growth in Lithuania. In order to verify if consistent patterns in investing as country develops exist, empirical evidence from Austria is to be thoroughly analysed and juxtaposed with Lithuanian practice.

\section{Overview of current growth and investment in the $\mathbf{E U}$}

The situation in 2006 was characterised by significant growth dispersion. Recently acceded member states continued to show a strong growth performance. This was particularly the case of the Baltic countries, which registered annual growth rates in the range of $7.5-10 \%$. Among the larger economies, the highest GDP growth was observed in the Czech Republic (6\%), followed by Hungary (4.1\%) and Poland (3.2\%). Among other non-Euro area member states GDP growth reached $3.1 \%$ in Denmark and $2.7 \%$ in Sweden, while in the UK the weakening of consumer spending compared with the previous year reduced growth to $1.8 \%$ (European Commission 2006) (Fig. 1).

At first sight, data reflecting GDP growth and fixed investment formation, expressed in GDP percentage form, complies with classical theory asserting that fixed investment is one of the main factors of economic growth. It is worth to mention that developed countries invest less than the new EU members. Lower investment rate coincides with weaker economic growth in

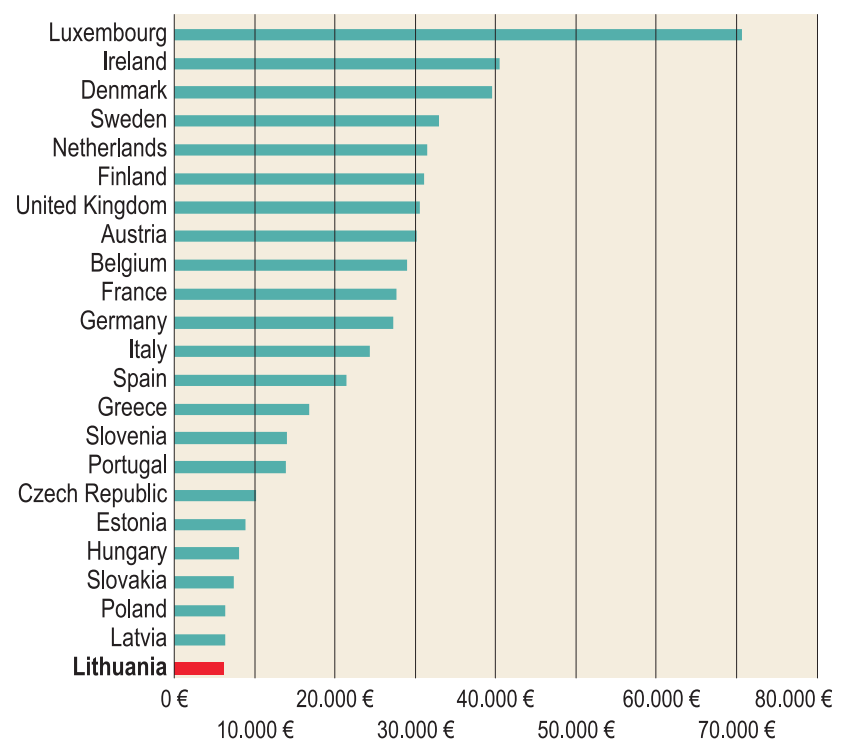

Fig. 2. GDP per capita in Europe in 2006; source: EUROSTAT 
the old EU countries (tendency described by P. Caselli (Caselli et al. 2003)). It might mean that at certain stages of development accumulation of fixed investment plays a different role - that is a premise, which we aim to elaborate in more detail.

The GDP per capita growth in Lithuania is impressive. How sustainable the growth is that is the issue of the highest importance. At the current moment Lithuania is attributed to a group of less developed European countries (Fig. 2). Thorough analysis of relationships between economic growth and fixed investments is supposed to provide some insights into prospects of Lithuania's development scenarios.

\section{Relationship between fixed investments and economic growth tendencies in Lithuania}

In order to detect relationship between fixed investment and economic growth Lithuania's data of transition period from 1993 until the current moment is be- ing analyzed. Dynamics of GDP per capita and investment growth per capita, both expressed in percentage terms, in Lithuania during the 1993-2006 period are presented below (Fig. 3).

Assumption is being made that country's GDP growth rate might depend on fixed investment structure change across five main capital formation sectors: agriculture, machinery, transport vehicles, construction and other products, which embrace investments into IT. More specific official titles of listed above activities and respective variables, which appear in our correlation analysis, are as follows: products of agriculture, forest$r y$, fisheries and aquaculture $\left(\mathrm{x}_{1}\right)$, metal products and machinery $\left(\mathrm{x}_{2}\right)$, transport equipment $\left(\mathrm{x}_{3}\right)$, construction work $\left(\mathrm{x}_{4}\right)$, other products $\left(\mathrm{x}_{5}\right)$. Dependent variable $(\mathrm{y})$ is GDP growth, in per cent. Tendencies of fixed investment change across the main capital formation sectors listed above during considered period are presented in Fig. 4. Exact statistical data, which are being used for further calculations are displayed in Table 1. For ana-

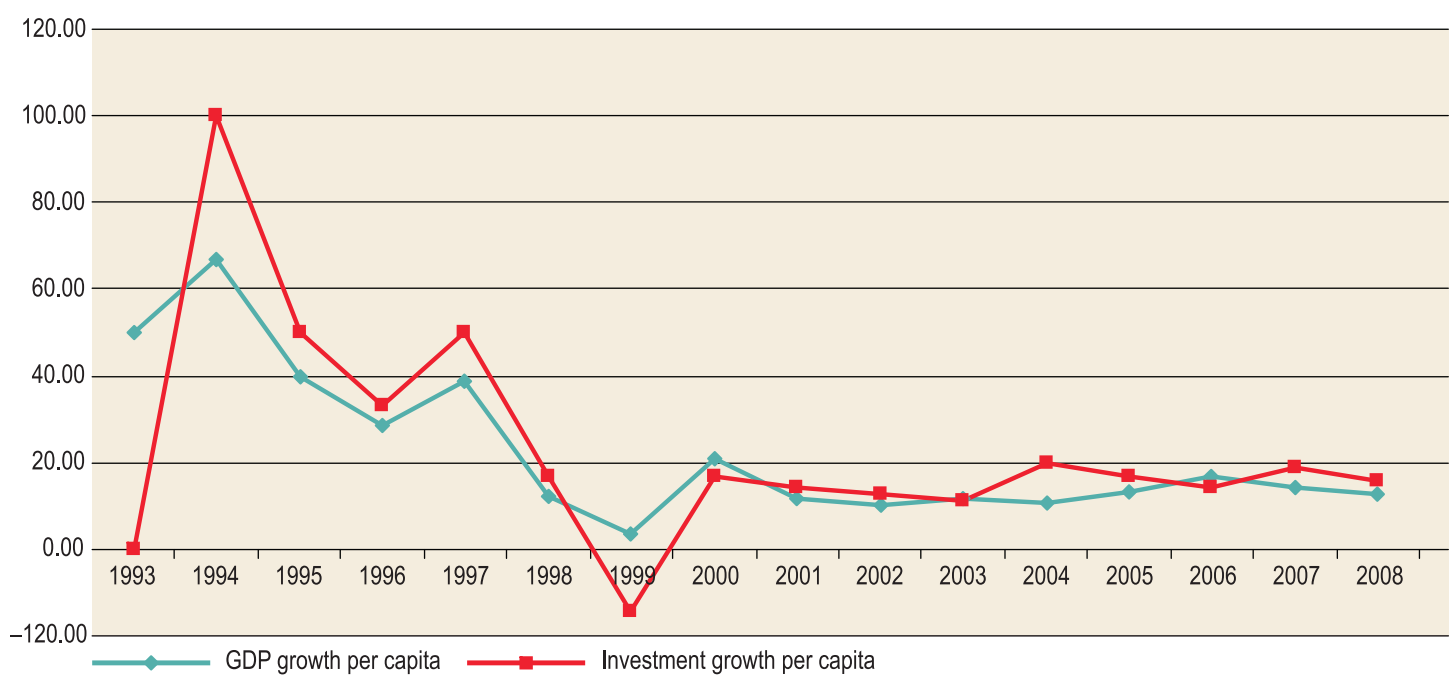

Fig. 3. GDP and investment per capita growth, \% (source: EUROSTAT, ratios calculated by the authors)

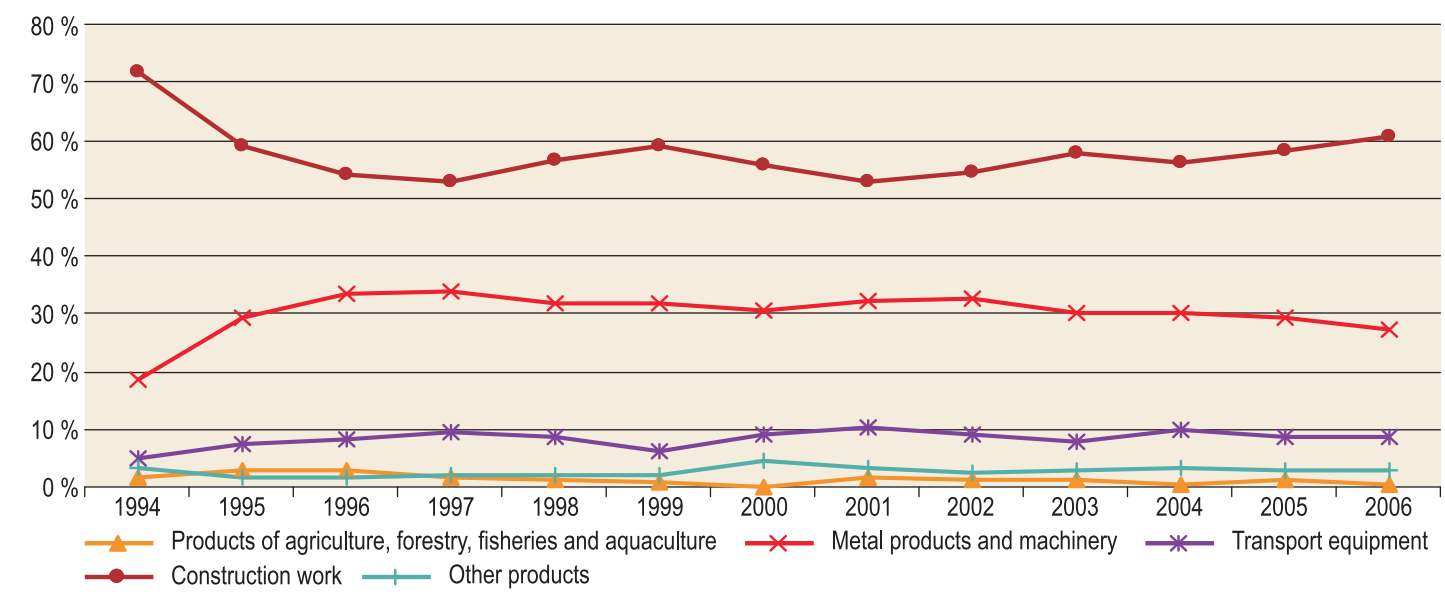

Fig. 4. Structure of fixed investments by 5 asset types in Lithuania 
lytical purposes, in order to have possibility to compare investment structure at a glance with other countries, authors calculated average per cent of investments into each activity, during 1994-2006, which is presented in the very last line of Table 1 .

The second step of the carried out research include determining of quantitative impact of fixed investment change in each activity on GDP growth. For that purpose data presented in Table 1 are being expressed in a different format: change of considered variables is shown in percentage growth terms. Data obtained by calculating year by year investment and GDP growth rate are used in further analysis and averages of change are shown in Table 2. Correlation analysis of change of fixed investments in each activity of capital formation and GDP change has been performed. Obtained correlation coefficients are presented in the very last line of Table 2 .

Table 1. Percent distribution of fixed investments across main economic sectors

(Source: EUROSTAT)

\begin{tabular}{ccccccc}
\hline Year & $\begin{array}{c}\text { Products of } \\
\text { agriculture, forestry, } \\
\text { fisheries and } \\
\text { aquaculture, } \%\end{array}$ & $\begin{array}{c}\text { Metal } \\
\text { products and } \\
\text { machinery, \% }\end{array}$ & $\begin{array}{c}\text { Transport } \\
\text { equipment, } \%\end{array}$ & $\begin{array}{c}\text { Construction } \\
\text { work, } \%\end{array}$ & $\begin{array}{c}\text { Other } \\
\text { products, } \\
\text { \% }\end{array}$ & $\begin{array}{c}\text { Total fixed } \\
\text { investments as } \\
\text { percentage of GDP }\end{array}$ \\
\hline 1994 & 1.7 & 18.5 & 5.1 & 71.6 & 3.1 & 23.1 \\
\hline 1995 & 2.9 & 29.2 & 7.4 & 58.8 & 1.7 & 21.0 \\
\hline 1996 & 3.0 & 33.3 & 8.1 & 54.0 & 1.5 & 21.1 \\
\hline 1997 & 1.8 & 33.7 & 9.5 & 52.7 & 2.2 & 22.6 \\
\hline 1998 & 1.2 & 31.7 & 8.5 & 56.7 & 1.9 & 24.0 \\
\hline 1999 & 1.0 & 31.7 & 6.3 & 59.0 & 2.1 & 22.0 \\
\hline 2000 & 0.2 & 30.7 & 9.1 & 55.7 & 4.4 & 18.8 \\
\hline 2001 & 1.7 & 32.3 & 10.2 & 52.7 & 3.2 & 20.1 \\
\hline 2002 & 1.4 & 32.5 & 9.0 & 54.4 & 2.6 & 20.3 \\
\hline 2003 & 1.1 & 30.1 & 8.0 & 57.8 & 3.0 & 21.2 \\
\hline 2004 & 0.6 & 30.0 & 10.0 & 56.2 & 3.1 & 22.3 \\
\hline 2005 & 1.1 & 29.3 & 8.7 & 58.0 & 2.8 & 22.4 \\
\hline 2006 & 0.5 & 27.3 & 8.7 & 60.7 & 2.9 & 23.1 \\
\hline Average & $\mathbf{1 . 4 0}$ & $\mathbf{3 0 . 0 2}$ & $\mathbf{8 . 3 6}$ & $\mathbf{5 7 . 5 6}$ & $\mathbf{2 . 6 5}$ & $\mathbf{2 1 . 6 9}$ \\
\hline
\end{tabular}

Table 2. Relationship between change of fixed investments into particular activity and GDP growth in Lithuania ${ }^{1}$ (Source: EUROSTAT)

\begin{tabular}{|c|c|c|c|c|c|c|}
\hline Year & $\begin{array}{c}\text { Y } \\
\text { GDP } \\
\text { growth, \% }\end{array}$ & $\begin{array}{c}\mathrm{X}_{1} \\
\text { Products of agriculture, } \\
\text { forestry, fisheries and } \\
\text { aquaculture growth, \% }\end{array}$ & $\begin{array}{c}\mathrm{X}_{2} \\
\text { Metal } \\
\text { products and } \\
\text { machinery } \\
\text { growth, \% }\end{array}$ & $\begin{array}{l}\quad \mathrm{X}_{3} \\
\text { Transport } \\
\text { equipment } \\
\text { growth, \% }\end{array}$ & $\begin{array}{c}\mathrm{X}_{4} \\
\text { Construction } \\
\text { work growth, } \%\end{array}$ & $\begin{array}{c}\mathrm{X}_{\mathbf{5}} \\
\text { Other } \\
\text { products } \\
\text { growth, \% }\end{array}$ \\
\hline 2001 & 9.76 & 746.30 & 23.78 & 32.78 & 11.56 & -14.07 \\
\hline 2002 & 10.82 & -6.56 & 12.25 & -1.08 & 15.45 & -7.15 \\
\hline 2003 & 9.54 & -14.05 & 5.85 & 1.20 & 21.24 & 31.30 \\
\hline 2004 & 10.18 & -29.16 & 15.81 & 46.92 & 12.82 & 17.98 \\
\hline 2005 & 13.76 & 94.62 & 11.50 & -1.54 & 18.06 & 3.93 \\
\hline 2006 & 15.16 & -50.59 & 10.74 & 17.94 & 24.30 & 20.99 \\
\hline Average & 19.21 & 69.59 & 25.77 & 28.96 & 17.65 & 24.89 \\
\hline $\begin{array}{l}\text { Correlation } \\
\text { coeficient } \\
\left(\text { ryx }_{i}\right)\end{array}$ & & -0.091 & 0.870 & 0.843 & 0,230 & 0.255 \\
\hline
\end{tabular}

\footnotetext{
${ }^{1}$ GDP and investment growth is calculated by simple annual growth comparing with the previous year
} 
Correlation analysis results let us make the following comments. Insignificant and negative relationship was detected between investments into agriculture and economic growth. It was $1.1 \%$ of total investment in 2005 but it decreased almost by half in 2006 (Table 1). The amount of investments is not very high but, as analysis shows, it does not contribute properly to process of economic growth. The character of relationship might be one of the reasons why fixed investments into agriculture activity comprise only roughly a half of those compared to Lithuanian case.

Investments into "Metal products and machinery"are in the second place if to look at total investments structure (Table 1). That verifies importance of industry for Lithuania. Significant correlation (correlation coefficient 0.87 ) between change in those investments and economic growth is being determined (Table 2). High correlation coefficient indicates positive impact of investments into equipment on country's economic growth.

Positive, statistically significant but surprisingly small correlation (correlation coefficient 0.23 ) is found between increasing investment share in construction sector and total GDP. At this point we wanted to recall theoretical discussion which compound of fixed investments - into equipment or construction - might be more significant for economic growth. Considering Lithuanian case, it is clearly seen that the biggest part of investments goes to "Construction work" (Fig. 4 , Table 1). Results of performed correlation analysis suggest these investments influence GDP to a much smaller extent than it was expected. Economic interpretation of the finding would be formulated after comparison with situation in European country while it was at the similar stage of development.

It was found that highly significant correlation (correlation coefficient 0.84 ) was determined for transport equipment, which verifies the important role of transport sector played in development of Lithuania's economy.

Positive but rather week correlation was also found between investment into other products and GDP growth. Positive correlation coincides with theoretical pattern of country's economic development, which emphasizes expansion of service sector as country reaches over industrialization stage. Although taking into consideration all acceding candidates, Lithuania lags behind in developing its services and accounts for the smallest production and employment share in this sector.

The conclusion can be made that Lithuania should decrease investments into "Products of agriculture, for- estry, fisheries and aquaculture". Countries like Netherlands and UK had similar investment index but in time they reduced it dramatically. All other countries had also reduced their fixed investments in agriculture. Today the average investment percent in the old EU member states is about $0.3 \%$ of all fixed investment. The second notice is that Lithuania's biggest part of capital formation spending goes to "Construction work". Last year Lithuania invested about $60.7 \%$ of all investments (Table 1). Austria had a very similar investment rate in "Construction work" in the year 1996. After such peak of investments Austria had big problems with economic stability. Let us examine Austria's case in detail.

\section{Case of Austria}

Highly developed the old European country Austria in the year 1979 was nearly at the same stage of economic development as Lithuania is now. For analytical reasons we decided to trace how pattern of fixed investment changed as Austria developed and how that changing structure of investments was related to country's GDP growth. Juxtaposition of current Lithuanian fixed investment structure and Austria's in the year 1979 is displayed in Fig. 5.

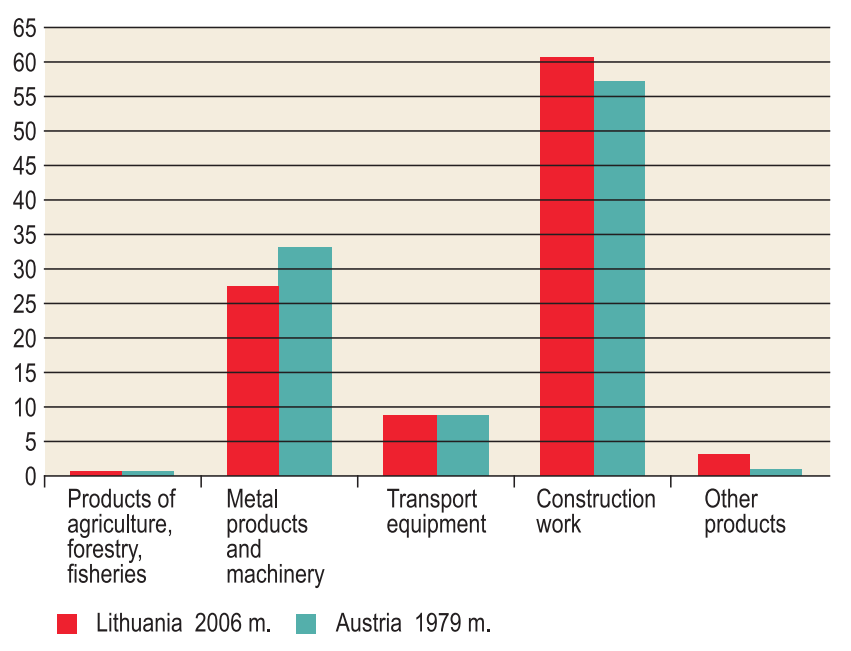

Fig. 5. Juxtaposition of current Lithuanian fixed investment structure and Austria's in the year 1979

Austria's fixed investments change into main capital formation activities as country developed is presented in Fig. 6.

Authors performed correlation analysis between the same variables as in Lithuanian case described above. The difference in approach is that in Austria's case the time span being used for analysis is longer (1979-2006) and divided into 3 shorter periods: 1979-1990, 1991-1999 and 2000-2006. The rationale 


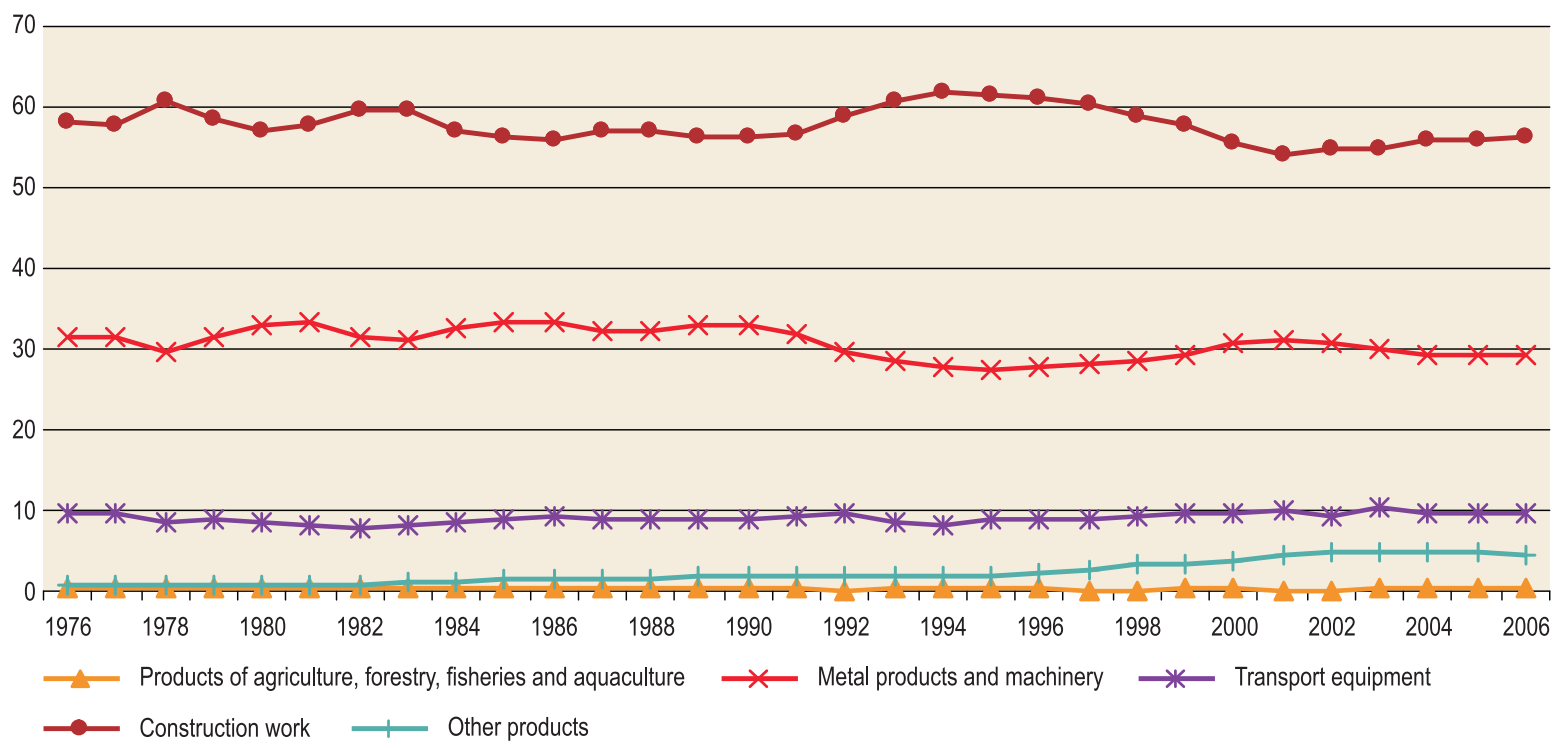

Fig. 6. Fixed investments by 5 asset types in Austria, \%

behind the division of statistical data into portions is related to purpose of the research: to trace if the stage of country's development leads to certain consistent patterns of fixed capital formation and, consequently, to specific implications for GDP growth.

Correlation coefficients and averages of fixed investment changes in considered activities during indicated time periods are presented in Table 2 .

The comments in the context of the outlined research are as follows. Investments in "Products of agriculture, forestry, fisheries and aquaculture" in Austria during all three considered periods were from 3 to 5 times smaller than Lithuania has had. (Fig. 3). Austria's correlation coefficient of "Products of agriculture, forestry, fisheries and aquaculture" is the smallest between other investment assets and it is almost equal to zero (Table 3 ). That means investments into agriculture actually have not impacted Austria's GDP growth.

Last decade Austria decreased investments in "Metal products and machinery" and "Construction work" but increased in "Other products". The analysis of the period 1977-1990 shows that the average increase of GDP was about $9.2 \%$ and the correlation coefficient between GDP growth and "Metal products and machinery" growth was 0.28 (Table 3 ). Notably, that specifically this period is characterized by high GDP growth, which has not been achieved in the higher stages of development. In Lithuania, which had comparable level of development with the one Austria had during 1977-1990, an impact of investment into equipment is much stronger (correlation coefficient 0.87 , Table 2). The difference in impacts might be attributed to differ- ent levels of technologies available at respective time periods. Now technologies are being spillovered rather easily, hence Lithuania can enjoy state-of-the-art technologies by investing into contemporary equipment.

Returning to Austria, during the years 1991-1999 its GDP grew just about $4.95 \%$ and correlation coefficient between some variables lowered more than twice, to 0.12 . In $2000-2006$ GDP growth coefficient was about $3.62 \%$ and correlation rate increased significantly and reached 0.72 . The average correlation rate over the whole time span of 1977-2006 was 0.48 . The conclusion could be drawn that investments in "Metal products and machinery" assets were increasingly impacting on GDP growth in Austria. It might be asserted that increasing complexity of technologies, implemented innovations affected the total factor of productivity and, respectively, more affected economic growth.

The highest correlation coefficient was detected between GDP growth and investments in "Construction work" (Table 3). In the years 1977-1990 it was 0.64, and in 1990-1999 it rose till 0.81. In 2000-2006 the same coefficient dropped to 0.58 . The average correlation rate during the period 1977-2006 was 0.74. The peak (61.9\% of all investments) of investments into construction work was recorded in 1994. One year later the GDP growth extremely slowed down and soon GDP growth coefficient became negative (-1.07) (Table 3). Soon after, Austria decreased investments in "Construction work" and increased investments in "Metal products and machinery". In result, GDP started to grow again. The conclusion can be drawn that the most important driver of GDP growth till 1995 was investments in "Construction work". Later, investments in "Metal products and machinery" became more important. 
As it was already mentioned above, the GDP growth in the period 1977-1990 was about $9.2 \%$ but in 2006 it grew just by $4.6 \%$ (Table 3 ). One reason of such slow down could be permanently growing investments into construction. After they have reached critical share the economy reacted by slowing down, what reversely restricted investments into "Construction work" activity. It is worth mentioning that the total fixed investments in 1977 in Austria comprised about $25 \%$ of GDP and in 2006 the share of them reduced to $21 \%$ of GDP. In Lithuania in the year 2006 fixed investments comprised $60.7 \%$ of the whole fixed investments. If to draw parallels to Austria, it might signal about nearing to a benchmark, after which investments into that activity and economy, respectively, responds by slowing down its growth. This effect in Lithuania, it is supposed, might be mitigated by lower impact of fixed investment into construction on economic growth.

Table 3. Relationship between structural investment and GDP growth in Austria

(Data source: EUROSTAT, calculations performed by authors)

\begin{tabular}{|c|c|c|c|c|c|c|}
\hline Year & $\begin{array}{c}\text { Y } \\
\text { GDP } \\
\text { growth, \% }\end{array}$ & $\begin{array}{c}\mathrm{X}_{1} \\
\text { Products of agriculture, } \\
\text { forestry, fisheries and } \\
\text { aquaculture growth, \% }\end{array}$ & $\begin{array}{c}\mathrm{X}_{2} \\
\text { Metal } \\
\text { products and } \\
\text { machinery } \\
\text { growth, \% }\end{array}$ & $\begin{array}{c}\quad \mathbf{X}_{3} \\
\text { Transport } \\
\text { equipment } \\
\text { growth, } \%\end{array}$ & $\begin{array}{c}\mathrm{X}_{4} \\
\text { Construction } \\
\text { work } \\
\text { growth, \% }\end{array}$ & $\begin{array}{c}\mathbf{X}_{5} \\
\text { Other } \\
\text { products } \\
\text { growth, \% }\end{array}$ \\
\hline $\begin{array}{l}\text { Correlation rate } \\
\text { (ryxi) } \\
1979-1990\end{array}$ & & -0.11 & 0.28 & 0.34 & 0.64 & -0.02 \\
\hline Average growth & 9.20 & 9.65 & 9.05 & 8.16 & 8.26 & 17.91 \\
\hline 1991 & 7.60 & -21.40 & 7.93 & 18.27 & 12.87 & 16.28 \\
\hline 1992 & 7.65 & -59.21 & -0.83 & 5.67 & 9.40 & -5.21 \\
\hline 1993 & 7.58 & 141.27 & 1.12 & -5.04 & 9.01 & 14.34 \\
\hline 1994 & 6.06 & 37.31 & 4.24 & 5.35 & 9.91 & 16.61 \\
\hline 1995 & 6.71 & -12.04 & 2.81 & 9.39 & 2.25 & 6.65 \\
\hline 1996 & 1.67 & -40.11 & 2.04 & 3.11 & 1.16 & 10.28 \\
\hline 1997 & -1.07 & -57.14 & 1.17 & 0.96 & -1.51 & 17.73 \\
\hline 1998 & 3.68 & 120.74 & 6.05 & 4.45 & 1.57 & 33.73 \\
\hline 1999 & 4.68 & 30.03 & 5.70 & 7.78 & 1.23 & 8.99 \\
\hline $\begin{array}{l}\text { Correlation rate } \\
\left(\mathrm{ryx}_{\mathbf{i}}\right) \\
1991-1999\end{array}$ & & 0.27 & 0.12 & 0.32 & 0.81 & -0.35 \\
\hline Average growth & 4.95 & 15.49 & 3.36 & 5.55 & 5.10 & 13.27 \\
\hline 2000 & 5.18 & 20.52 & 14.33 & 11.79 & 4.13 & 17.57 \\
\hline 2001 & 2.61 & -36.83 & 0.95 & 2.57 & -2.82 & 17.47 \\
\hline 2002 & 2.30 & 1.69 & -7.39 & -12.33 & -3.75 & 4.11 \\
\hline 2003 & 2.45 & 55.00 & 4.45 & 17.87 & 6.45 & 0.68 \\
\hline 2004 & 4.23 & 30.11 & 0.25 & -3.17 & 3.90 & 5.76 \\
\hline 2005 & 3.94 & 14.05 & 2.04 & 1.54 & 2.47 & 0.43 \\
\hline 2006 & 4.60 & -18.04 & 5.88 & 6.07 & 7.53 & 3.74 \\
\hline $\begin{array}{l}\text { Correlation rate } \\
\left(\mathrm{ryx}_{\mathrm{i}}\right) \\
\mathbf{2 0 0 0 - 2 0 0 6} \\
\end{array}$ & & 0.04 & 0.72 & 0.23 & 0.58 & 0.22 \\
\hline Average growth & 3.62 & 9.50 & 2.93 & 3.48 & 2.56 & 7.11 \\
\hline $\begin{array}{l}\text { Correlation rate } \\
\left(r y x_{i}\right) \\
1979-2006\end{array}$ & & 0.062 & 0.480 & 0.365 & 0.743 & 0.216 \\
\hline $\begin{array}{l}\text { Average growth } \\
\text { 1979-2006 }\end{array}$ & 6.62 & 11.37 & 5.91 & 6.28 & 5.98 & 14.00 \\
\hline
\end{tabular}




\section{Conclusions}

1. Not only amount of fixed investments plays a significant role in countries' development process, the structure of investment across economic activities matters as it affects rates of economic growth.

2. Main role in compounding parts of fixed investment is being attributed to equipment and construction capital formation activities. Impact of those constituents change on GDP growth varies across countries and, it is admitted, partly depends on achieved level of country's development.

3. Lithuanian case suggests that at the current stage of development the most important role is played by investments into "Metal products and machinery" and "Transport equipment". Investment into "Products of agriculture, forestry, fisheries and aquaculture" almost does not affect economic growth.

4. Lithuania's investment strategy is seen as rather very similar to that in Austria when it had the same GDP per capita as Lithuania has at the current moment. Thorough analysis of Austria's case supported assumption that certain consistent patterns of development exist and less developed countries in a certain sense replicate the path of development. Taking into account Austria's investment and economic growth pattern and applying it for Lithuanian case, it can be predicted that at the current stage of development heavy lasting investments into construction may cause threat to rapid economic growth and lead to the decrease in both, fixed investment into construction and rates of GDP growth.

\section{References}

Blomstrom, M.; Lipsey, R. E.; Zejan, M. 2001. Is fixed investment the key to economic growth? Working Paper No. 4436. National Bureau of Economic Research, Cambridge, MA.

Carone, G.; Cécile, D.; Mc Morrow, K.; Mourre, G.; Werner, R. 2006. Long-term labour productivity and GDP projections for the EU25 Member States: a production function framework, MPRA Paper No. 744, August.

Caselli, P.; Pagano, P.; Schivardi, F. 2003. Uncertainty and the slowdown of capital accumulation in Europe, Applied Economics 35(1): 79-89.

De Long, J. B. 1992. Productivity growth and machinery investment: A long-run look, 1870-1980, The Journal of Economic History 52(2): 307-324.

De Long, J. B.; Summers, L. H. 1991. Equipment investment and economic growth, Quarterly Journal of Economics, May: 445-502.

De Long, J. B.; Summers, L. H. 1994. Equipment investment and economic growth: A reply, Quarterly Journal of Economics 109: 803-807.

Dellas, H.; Koubi, V. 2001. Industrial employment, investment equipment and economic growth, Economic Development and Cultural Change 49(4): 867-881.

European Commission. Economic forecasts Spring 2006. Luxemburg. 2006, Issue 2.

EUROSTAT. Available from Internet: < http://ec.europa.eu/ eurostat.>. 